\title{
CHLOROPHYLL $a$ FLUORESCENCE OF GONYAULAX POLYEDRA GROWN ON A LIGHT-DARK CYCLE AND AFTER TRANSFER TO CONSTANT LIGHT
}

\author{
Govindjee*, D. Wong, Barbara B. Prézelin† \\ and BEATRICE M. SWEENEY† \\ Departments of Physiology and Biophysics and Botany, University of Illinois, \\ Urbana, IL 61801, U.S.A. and \\ $\nmid$ Department of Biological Sciences and Marine Science Institute, \\ University of California, Santa Barbara, CA 93106, U.S.A.
}

(Received 15 December 1978; accepted 3 April 1979)

\begin{abstract}
The chlorophyll $a$ fluorescence properties of Gonyaulax polyedra cells before and after transfer from a light-dark cycle (LD) to constant dim light (LL) were investigated. The latter display a faster fluorescence transient from the level 'I' (intermediary peak) to ' $D$ ' (dip) to 'P' (peak) than the former ( $3 \mathrm{~s}$ as compared to $10 \mathrm{~s}$ ), and a different pattern of decline in fluorescence from 'I' to 'D' and from ' $P$ ' to the steady state level with no clearly separable second wave of slow fluorescence change, referred to as ' $S$ ' (quasi steady state) $\rightarrow$ 'M' (maximum) $\rightarrow$ ' $T$ ' (terminal steady state). The above differences are constant features of cells in LD and LL, and are not dependent on the time of day. They are interpreted as evidence for a greater ratio of photosystem II/photosystem I activity in cells in LL.

After an initial photoadaptive response following transfer from $L D$ to $L L$, the cell absorbance at room temperature and fluorescence emission spectra at $77 \mathrm{~K}$ for cells in LL and LD are comparable. The major emission peak is at $685-688 \mathrm{~nm}$ (from an antenna $\mathrm{Chl} a 680$, perhaps Chl $a-c$ complex), but, unlike higher plants and other algae, the emission bands at 696-698 nm (from Chl $a_{11}$ complex, Chl $a$ 685, close to reaction center II) and $710-720 \mathrm{~nm}$ (from Chl $a_{1}$ complexes, Chl $a$ 695, close to reaction center I) are very minor and could be observed only in the fluorescence emission difference spectra of LL minus LD cells and in the ratio spectra of DCMU-treated to non-treated cells.

Comparison of emission spectra of cells in LL and LD suggested that, in LL, there is a slightly greater net excitation energy transfer from the light-harvesting peridinin-Chl $a$ (Chl $a$ 670) complex, fluorescing at $675 \mathrm{~nm}$, to the other antenna chlorophyll $a$ complex fluorescing at $685-688 \mathrm{~nm}$, and from the Chl $a_{\text {II }}$ complex to the reaction center II. Comparison of excitation spectra of fluorescence of LL and LD cells, in the presence of DCMU, confirmed that cells in LL transfer energy more extensively from the peridinin-Chl $a$ complex to other Chl $a$ complexes than do cells in LD.
\end{abstract}

\section{INTRODUCTION}

Photosynthesis in the dinoflagellate Gonyaulax polyedra is under the control of a circadian oscillator (Hastings et al., 1961; Prézelin and Sweeney, 1977). Photosynthesis in other dinoflagellates (Prézelin et al., $1977)$ and in naturally occurring phytoplankton assemblages (Prézelin, 1978) is also rhythmic; hence, the phenomenon is of general importance (see Sweeney and Prézelin, 1978). Prézelin and Sweeney (1977) demonstrated that the room temperature chlorophyll (Chl) $a$ fiuorescence of Gonyaulax, plotted as the ratio of fluorescence intensity measured $30 \mathrm{~s}$ to $1 \mathrm{~min}$ after the beginning of irradiation to that in the presence of 3-(3,4 dichlorophenyl) 1,1, dimethylurea (DCMU), is rhythmic with a maximum value in the middle of the night phase of the circadian cycle. This finding

* Please send all correspondence to: Govindjee, Department of Botany, 289 Morrill Hall, University of Illinois, Urbana, IL 61801 U.S.A.

Abbreviations: Chl $a$, chlorophyll $a$; DCMU, 3-(3,4 dichlorophenyl) 1,1'dimethylurea; PS I, photosystem I; PS II, photosystem II; LD, light-dark cycle; LL, continuous light. sparked our interest in exploring other rhythmic characteristics of fluorescence in the hope of explaining the manner in which the photosynthetic apparatus is linked to the circadian oscillator. The rhythmic fluorescence parameters are described in another paper (Sweeney et al., 1979). To our knowledge, there are no previous measurements of the fluorescence characteristics of the dinoflagellates, in which the photosynthetic pigments include the peridinin-chlorophyllprotein (not found in other algal groups, Prézelin and Haxo, 1976). Thus, we present here several fluorescence characteristics of the dinoflagellate Gonyaulax under two conditions, an entraining light-dark cycle (LD) and constant light and temperature (LL), used to detect the presence of a circadian oscillation as distinct from a process responsive to light or darkness (Sweeney, 1977): (1) fluorescence induction that provides information on the activity of photosystem II of photosynthesis and its interaction with photosystem I (see Govindjee and Papageorgiou, 1971; Mohanty and Govindjee, 1974; Papageorgiou, 1975; Lavorel and Etienne, 1977); (2) fluorescence emission spectra that provide information on the presence of 
different fluorescent species and on the excitation energy transfer among them (see Goedheer, 1972; Govindjee et al., 1973); and (3) fluorescence excitation spectra that provide information on the different absorbing species that fluoresce or transfer energy to the fluorescent species.

\section{MATERIALS AND METHODS}

Culture conditions. Gonyaulax polyedra Stein, clone $70 \mathrm{~A}$, was grown in unialgal batch cultures in $2-\ell$ Erlenmeyer flasks containing $1 \ell$ of $\mathrm{f} / 2$ medium (Guillard and Ryther, 1962). Overhead illumination was provided by banks of cool-white fluorescence lamps $\left(1 \mathrm{mWcm}^{-2}\right)$. Cells were cultured on an alternating $12 \mathrm{~h}$ light-dark schedule (LD) at $22^{\circ} \mathrm{C}$. Half of the cultures were transferred from LD at the beginning of the light period to continuous light (LL) at an illumination of $0.5 \mathrm{mWcm}^{-2}$. Experimental measurements were begun after 2 days in $L L$.

Sampling methods. At each experimental measurement time, a $50-\mathrm{m} \ell$ suspension of late exponential cells $\left(7 \times 10^{3}\right.$ cells $\left./ \mathrm{m} \ell\right)$ was harvested by gentle centrifugation (room temperature, $3 \mathrm{~min}, \sim 400 \times \mathrm{g}$ ) and resuspended in $3.0 \mathrm{~m} \ell$ of fresh $\mathrm{f} / 2$ medium. A $0.2-\mathrm{m} \ell$ aliquot was taken for cell counts. All experimental results are expressed on a per cell basis. This was an acceptable method because there was no significant change in the gross pigment content of the cells. The remaining sample was incubated in the dark for $10 \mathrm{~min}$ and the room temperature fluorescence was measured. The sample was then divided, $1.0 \mathrm{~m} /$ being dark-adapted, adsorbed on cheesecloth, and cooled quickly to liquid nitrogen temperature $(77 \mathrm{~K})$ for low temperature fluorescence measurements. The remaining $1.8 \mathrm{~m} \ell$ of cells were used to establish that a circadian rhythm indeed existed in the rates of photosynthetic oxygen evolution in both LD and LL cells used in the present study (see Sweeney et al., 1979).

Pigment determination. Estimates of the chlorophyll content of cultures in LD and LL were made by harvesting $50 \mathrm{~m} \ell$ of each culture by gentle membrane filtration, extracting overnight in cold $90 \%$ acetone with $\mathrm{MgCO}_{3}$, and determining the absorption spectra of the acetone supernatants. Chlorophyll $a$ and $c$ concentrations were calculated from the equations of Jeffrey et al. (1975). For pigments in vivo, absorption spectra of cells suspended in $40 \%$ ficoll (to reduce settling) were measured with a Cary $14 \mathrm{R}$ spectrophotometer by scanning the suspensions against adjusted scattering samples of freshly prepared $\mathrm{BaSO}_{4}$ in $40 \%$ ficoll.

Fluorescence measurements. Low temperature $(77 \mathrm{~K})$ fluorescence emission spectra were measured with the spectrofluorometer described by Shimony et al. (1967) and by the methods described by Cho (1969). Front surface fluorescence was detected by an EMI 9558B photomultiplier (S-20 response) through a Corning CS 2-61 sharp cut-of glass filter (thickness, $2.5 \mathrm{~mm}$ ) and a Bausch and Lomb monochromator (blazed at $750 \mathrm{~nm}$; band pass, $1.0 \mathrm{~nm}$ ). This narrow band width $( \pm 0.5 \mathrm{~nm})$ permitted resolution of peaks separated by $1.0 \mathrm{~nm}$. Fluorescence was excited with a Radiant Lamp Corporation (Newark, N.J.) DDY $750 \mathrm{~W}$ tungsten filament projection lamp through heat filters and a combination of Corning CS 3-73 and CS 4-96 glass filters (maximum, $\sim 480 \mathrm{~nm}$; half-maximum band-width $\sim 150 \mathrm{~nm}$ ). The light flux at the sample measured with a Yellow Springs radiometer (Model No. 63) was $200 \mathrm{~W} \mathrm{~m}^{-2}$. The photocurrent from the photomultiplier was converted to voltage (using an operational amplifier and a feedback resistor of $10^{8} \mathrm{ohms}$ ), passed through a low pass filter (time constant, $100 \mathrm{~ms}$ ), and displayed on a strip-chart Esterline Angus recorder (Model, E 1101S). The wavelength scan speed was $100 \mathrm{~nm} / 90 \mathrm{~s}$. Emission spectra were corrected, point by point, for photomultiplier sensitivity and transmission characteristics of the mono- chromator. For the $77 \mathrm{~K}$ excitation spectra of fluorescence at $750 \mathrm{~nm}$ (band pass, $6.6 \mathrm{~nm}$ ), the samples were excited with a microscope illumination lamp (tungsten ribbon filament, General Electric Type 18A/T10/1P-6V) through a Bausch and Lomb monochromator (blazed at $300 \mathrm{~nm}$; band pass, $9.9 \mathrm{~nm}$ ). The excitation spectra were corrected for the numbers of incident quanta. A fast camera shutter between the projection lamp and the sample was used for measurements of fluorescence transients (for details, see Munday and Govindjee, 1969). For samples at room temperature, the photomultiplier signal was amplified with a Tektronix 502 oscilloscope and displayed on a strip-chart recorder. At $77 \mathrm{~K}$, a Biomation Waveform recorder (Model 805 ) was used instead of the oscilloscope.

\section{RESULTS}

\section{Pigment content}

Chlorophyll $a$ content, from the pigment extraction data, was within a narrow range (3) to $3.5 \times 10^{-14} \mathrm{~mol} \mathrm{cell}^{-1}$ ) for LD cells and cells in LL after 2 days of transfer, cells in LL containing only slightly less chlorophyll than cells in LD. Chlorophyll $c_{2}$ content was also within a narrow range (2 to $2.3 \times 10^{-14} \mathrm{~mol}$ cell), cells in LL again containing only slightly less than cells in LD. Although LL cells had presumably undergone an initial photoadaptive response upon transfer to continuous illumination, the pigment analysis and the absorption spectra (not shown) confirm that total pigmentation and gross absorbance of LL and LD cells are not significantly different at the time of comparison as noted earlier by Prézelin et al. (1977) and Prézelin and Sweeney (1977). We, however, noted small but important differences in the absorption spectra: a slight (1-2 nm) shift

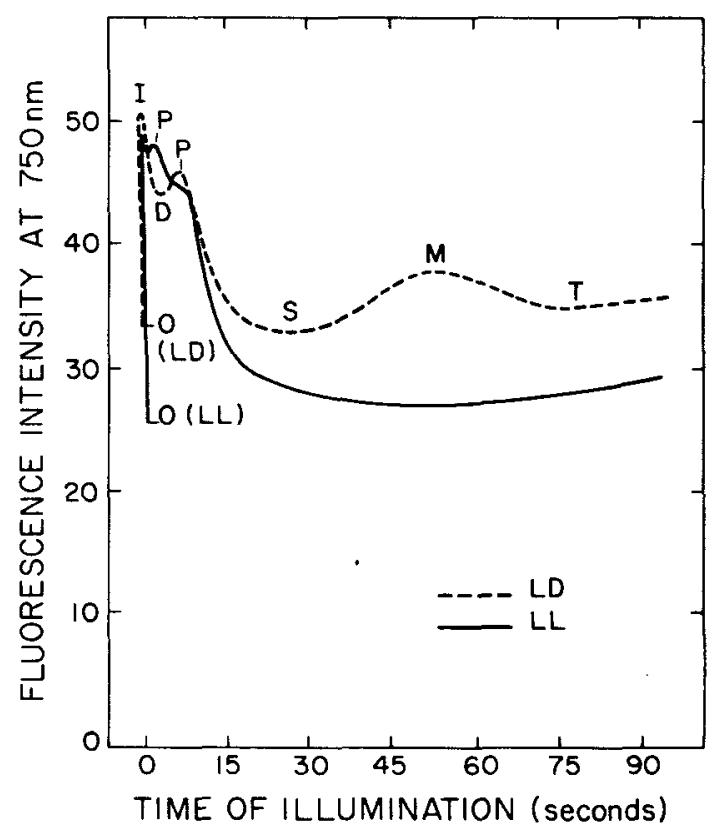

Figure 1. Chlorophyll $a$ fluorescence transients of $G$ polyedra cultured on a light-dark cycle ( $\mathrm{LD}$, dashed tine) and transferred to continuous dim illumination ( $L L$, solid line). See text for definition of symbols. Temperature, $22^{\circ} \mathrm{C}$. Dark adaptation, $10 \mathrm{~min}$ 
of the red peak to the long wavelength side and a decreased ratio of absorbance by long wavelength to short wavelength spectral forms of Chl $a$ in LL $(\sim 0.05)$ than in $\mathrm{LD}(\sim 0.10)$ cells.

\section{Fluorescence transients}

Features of chlorophyll $a$ fluorescence induction curves (Fig. 1) that characterize LL cells as being distinct from LD cells are: (1) the ratio of intermediary peak ' $\mathrm{I}$ ' to dip ' $\mathrm{D}$ ' is smaller; (2) peak ' $\mathrm{P}$ ' is almost as high as ' $\mathrm{I}$ '; (3) ' $\mathrm{P}$ ' is reached earlier, within $3 \mathrm{~s}$, as opposed to $10 \mathrm{~s}$ in LD cells; (4) the 'P' to ' $T$ ' (terminal steady state) transient goes through a hump at about 10 s that may represent the maximum ' $M$ '; (5) the usual $S$ (quasi-steady state) $\rightarrow M \rightarrow T$ transient is obscured due to the presumably early appearance of ' $M$ '; these 'SMT' changes were not observed in LL at any intensity used; (6) the ratio of the maximum variable $(\Delta F ; \mathrm{P}-\mathrm{O})$ to the so-called "constant" $(\mathrm{O})$ fluorescence is higher in LL cells, and finally, (7) the ' $O$ ' level is lower in LL than in LD cells.

Since the ' $O$ ' level originates in both PS I and PS II and the variable fluorescence $(\Delta F)$ only in PS II (Govindjee and Papageorgiou, 1971), both the lower ' $O$ ' level and higher $\Delta F / O$ ' ratio indicate the greater ratio of PS II/PS I activity in LL cells. This conclusion is supported by the kinetic differences described above as a higher ratio of PS II to PS I activity leads to faster removal of the quencher $Q$ (see Duysens and Sweers, 1963) and, thus, of an earlier appearance of ' $P$ '. Differences in 'SMT' changes are, however, due to changes in the thylakoid membrane (see Discussion).

The above characteristic differences in the fluorescence induction curves were constant features of LD and LL cells and were arhythmic.

\section{Fluorescence emission}

The fluorescence emission properties of cultures in LD and LL were compared to see if the initial photoadaptive response of LL cells had resulted in a change in the relative proportion of different $\mathrm{Chl} a$ forms and/or in their energy transfer distribution leading to changes in PS II/PS I activity ratios noted above. A low-temperature $(77 \mathrm{~K})$ emission spectrum of LD night phase cells of G. polyedra (Fig. 2, dashed curve) shows the major $\mathrm{Chl} a$ emission maximum at about $688 \mathrm{~nm}$ and small fluorescence inflections at about $670-675,705-710$ and $725-735 \mathrm{~nm}$. The emission band of $\mathrm{Chl} a$ in the peridinin-Chl a-protein (PCP) is at 672-675 nm (Prézelin and Haxo, 1976; Song et al., 1976; Koka and Song, 1977) and, thus, accounts for the $675 \mathrm{~nm}$ emission band seen in the whole cell fluorescence emission spectrum of Gonyaulax. The $688 \mathrm{~nm}$ emission band is ascribed to the remaining light-harvesting $\mathrm{Chl} a$-proteins (Thornber et al., 1976; Prézelin and Alberte, 1978). By analogy to other systems (see Govindjee et al., 1973), the long wavelength bands $(705-735 \mathrm{~nm})$ are suggested to originate in $\mathrm{Chl} a$ in PS I.

The $77 \mathrm{~K}$ emission spectrum for LL cells (Fig. 2, solid curve) appeared qualitatively similar to that of LD cells, except that the major emission maximum was blue-shifted by $1 \mathrm{~nm}$ to $687 \mathrm{~nm}$, accompanied by a narrowing of the band on the longwave side. The difference spectrum of the $77 \mathrm{~K}$ fluorescence emission of $L L$ and $L D$ cells $[F(L L)-F(L D)]$ (Fig. 2, inset) provides resolution of an emission band at $690-695 \mathrm{~nm}$ (from $\mathrm{Chl} a_{\mathrm{II}}$ ), and suggests that a difference exists in its relative intensity in LL and LD cells. This is not due to a shift in the absorbance bands as that shift is to the red end of the spectrum, in contrast to the blue shift in the emission spectra for

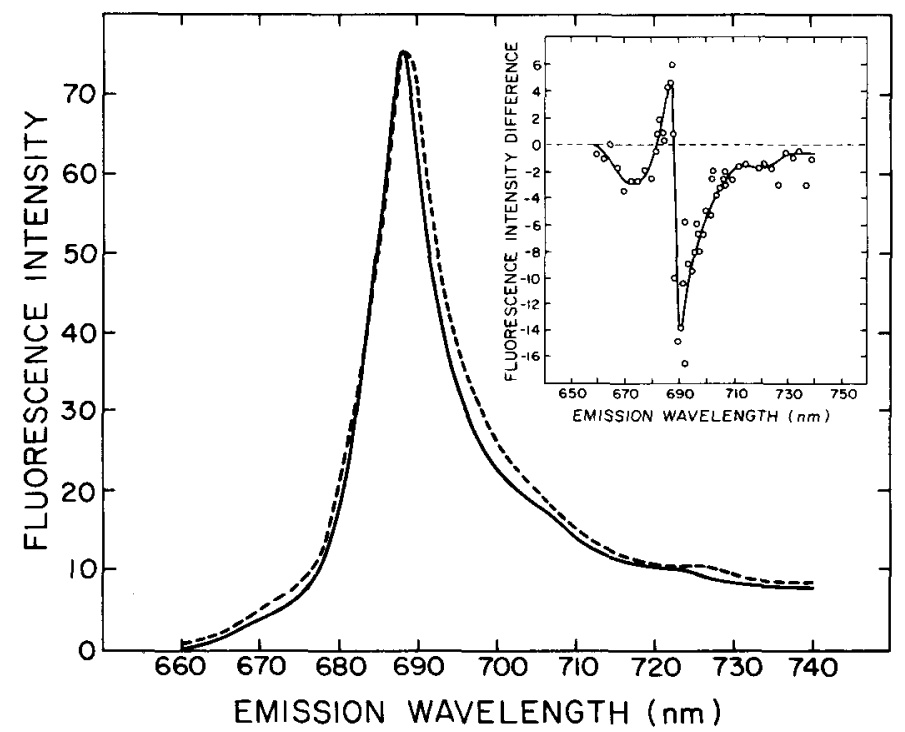

Figure 2. Fluorescence emission spectra of $G$. polyedra cultured on a light-dark cycle (LD, dashed line) and transferred to continuous dim illumination ( $\mathrm{LL}$, solid line). Temperature, $77 \mathrm{~K}$. Band pass, $1.0 \mathrm{~nm}$. Excitation, broad band blue light. Inset: Difference spectrum, $F(L L)-F(L D)$, of low temperature $(77 \mathrm{~K})$ fluorescence emission spectra of $G$. polyedra. 


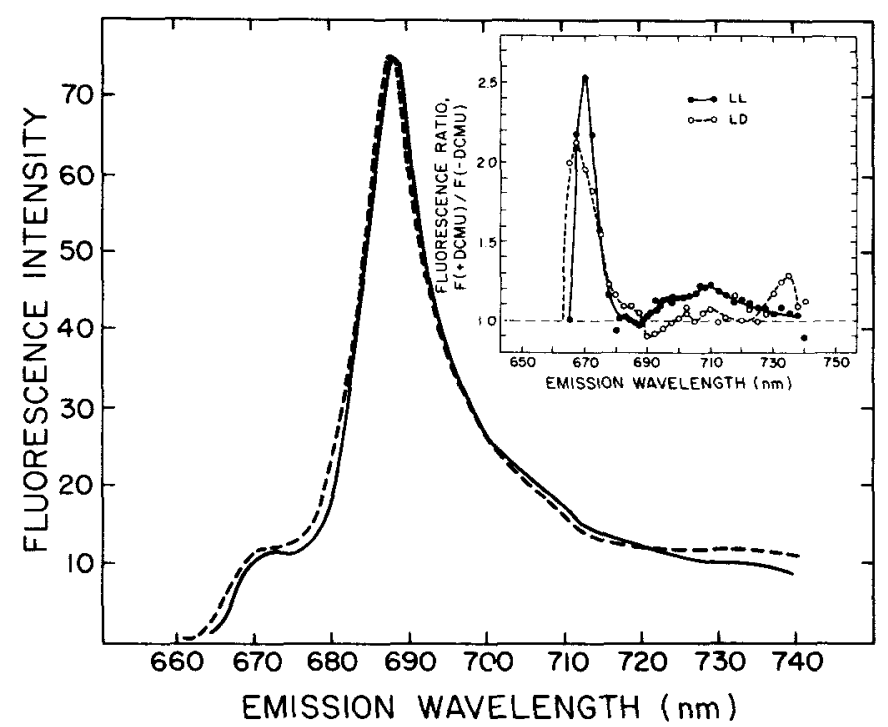

Figure 3. Fluorescence emission spectra of $G$. polyedra cultured on a light-dark cycle (LD, dashed line) and transferred to continuous dim illumination ( $\mathrm{LL}$, solid line). Measurements were made in the presence of $10 \mu \mathrm{M}$ DCMU. Temperature, $77 \mathrm{~K}$. Bandpass, $1.0 \mathrm{~nm}$. Excitation, broad band blue light. Inset: Ratio spectra $\mathrm{F}(+\mathrm{DCMU}) / \mathrm{F}(-\mathrm{DCMU})$ of low temperature $(77 \mathrm{~K})$ emission spectra of $G$. polyedra, measured in the presence $(+)$ and absence $(-)$ of $10 \mu \mathrm{M}$ DCMU. Cells were cultured on a light-dark cycle (LD, dashed line) and transferred to continuous dim illumination (LL, solid line).

LL as compared to LD cells. The simplest interpretation of the difference bands (Fig. 2, inset) is an increased energy transfer from peridinin-Chl complex (fluorescing at $675 \mathrm{~nm}$ ) to other complexes (fluorescing at $685 \mathrm{~nm}$ ), and from $\mathrm{Chl} a_{\mathrm{II}}$ (fluorescing at $690-695 \mathrm{~nm}$ ) to the reaction center II in LL than in LD cells. Some of these conclusions were confirmed by results on excitation spectra (see later), and are consistent with the earlier interpretation of a greater ratio of PS II/PS I activities in LL than in LD cells.

Figure 3 sh ,ws the emission spectra of LL (solid line) and LD (dashed line) night phase cells in the presence of $10 \mu \mathrm{M} \mathrm{DCMU}$, and the inset shows the effect of DCMU on the emission spectra, plotted as ratio spectra $F(+D C M U) / F(-D C M U)$, for cells in LD and LL. The main changes due to DCMU addition seem to be increases in emission at 670-675 (from $\mathrm{Chl} a$ in PCP), 695-700 (Chl $a_{11}$ ) and $710 \mathrm{~nm}$ (Chl $a_{1}$ ). Since reaction center II is closed in the presence of DCMU, the increases at 670-675 and 695-700 nm are interpreted as a net decrease in energy transfer from PCP and Chl $a_{11}$ to reaction center II. This must increase the excited state lifetimes in PCP and Chl $a_{11}$ leading to a small net increase in energy transfer to $\mathrm{Chl} a_{1}$ giving the peak at $\sim 710 \mathrm{~nm}$ in the inset. The increases in several Chl $a$ emission bands upon closure of reaction center II, observed here, are consistent with the earlier observations at room temperature on the effects of DCMU on changes in excitation energy transfer, as deduced from changes in the degree of polarization of fluorescence (Mar and Govindjee, 1972; Govindjee and Wong, 1978; Van Rensen et al., 1978) and in the emission spectra (Krey and Govindjee, 1966; Govindjee and Briantais, 1972; Van
Rensen et al., 1978) in Porphyridium, Chlorella and in chloroplasts from higher plants. Differences between LL and LD cells are mainly due to slight changes in absorption spectra.

\section{Fluorescence excitation}

Differences in LL and LD fluorescence properties were observed in the $77 \mathrm{~K}$ excitation spectra of $\mathrm{Chl}$ $a$ fluorescence measured at $750 \pm 9 \mathrm{~nm}$ in $G$. polyedra cells poisoned with $10 \mu \mathrm{M}$ DCMU (Fig. 4). In both LL (solid line) and LD (dashed line) cells, the excitation spectra corrected for numbers of incident photons showed a striking difference from the absorption spectra of the same cell suspensions. Between 400 and $500 \mathrm{~nm}$, the excitation spectra are much lower, as compared to the $\mathrm{Chl} a$ band around $675 \mathrm{~nm}$. This must be due to a very low average efficiency of excitation energy transfer from carotenoids (diadinoxanthin and dinoxanthin) and/or due to the fact that some carotenoids are not in the photosynthetic machinery and act as filters of incident light falling on the thylakoids. Such conclusions have been made earlier from other systems (Emerson and Lewis, 1942; Duysens, 1952; see also Goedheer, 1972; Boardman et al., 1978).

That PCP (fluorescing at $670-675 \mathrm{~nm}$ ) is more effective in LL cells in transferring energy to the antenna Chl $a$ fluorescing at $685 \mathrm{~nm}$, was suggested by the fluorescence emission difference spectrum (Fig. 2, inset). In the presence of DCMU, the ratio of effectiveness of PCP to $\mathrm{Chl} a$, as shown in the difference excitation spectrum for $750 \mathrm{~nm}$ fluorescence of LL and LD cells (Fig. 4, bottom), further suggests a more effective energy transfer to Chl $a$ forms fluor- 


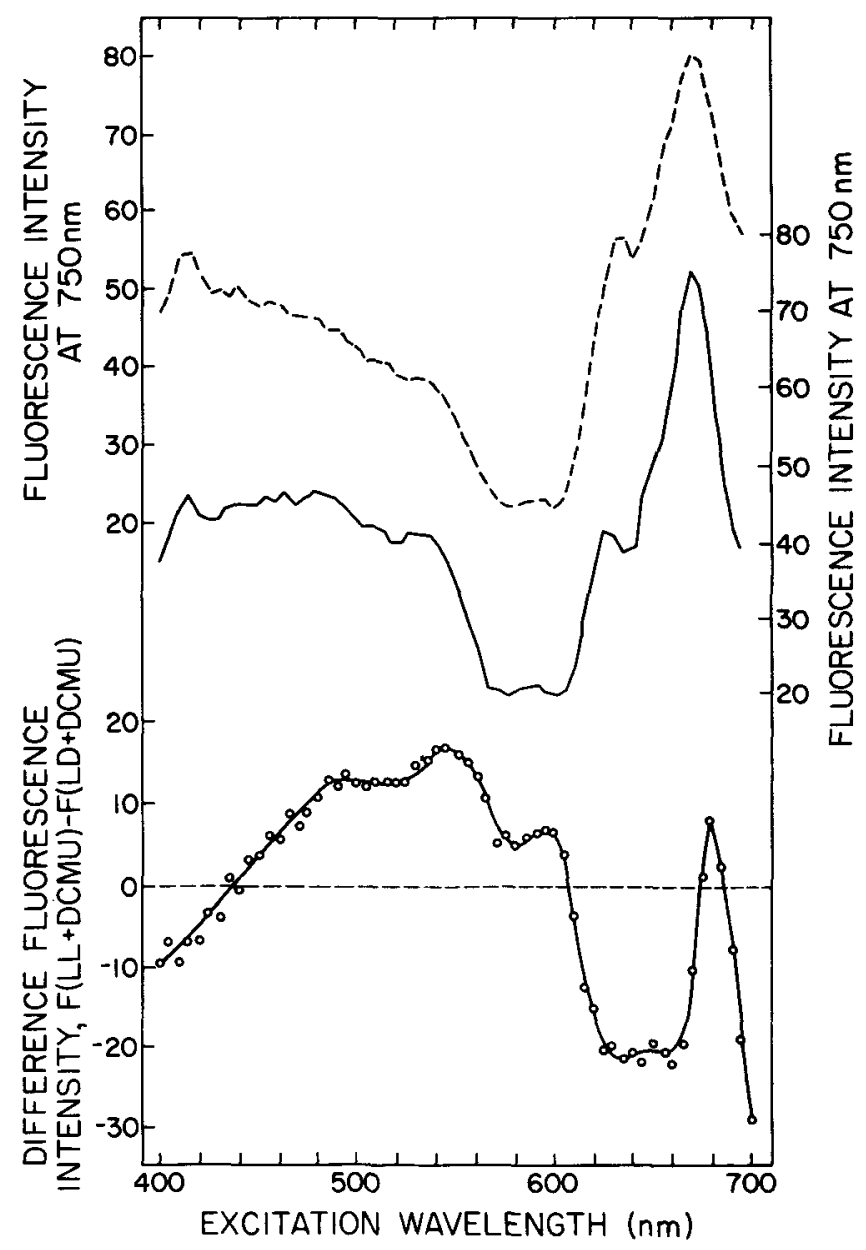

Figure 4. Fluorescence excitation spectrum of $G$. polyedra cultured on a light-dark cycle (LD, dashed line; top curve) and under continuous dim illumination (LL, solid line; middle curve) measured in the presence of $10 \mu \mathrm{M}$ DCMU. Temperature, $77 \mathrm{~K}$. Slitwidth, $10.0 \mathrm{~nm}$. Measuring wavelength, $750 \pm 9 \mathrm{~nm}$. Difference spectrum [F(LL + DCMU) - F(LD + DCMU)] of $77 \mathrm{~K}$ fluorescence excitation spectra (bottom curve).

escing at $750 \mathrm{~nm}(\mathrm{~F} 750)$ in LL cells. The excitation difference spectrum of $F 750$ between $L L$ and $L D$ cells treated with DCMU resembles the absorption spectrum of PCP at low temperatures (Prézelin and Haxo, 1976).

\section{DISCUSSION}

(1) Fluorescence transients: higher ratio of activity of PS II to PS I in LL cells

The present study of the fluorescence properties of G. polyedra, showing changes induced in some fluorescence parameters by the transfer of cells from LD and LL conditions, led to new information on the nature of the photosynthetic apparatus of dinoflagellates. The most important feature of $G$. polyedra fiuorescence data is the difference between the fluorescence induction curves of LL and LD cells. The LD cells show the fast fluorescence $(\mathrm{O} \rightarrow \mathrm{I} \rightarrow \mathrm{D} \rightarrow \mathrm{P}$ ), followed by a decline to the ' $\mathrm{S}$ ' level and the usual slow 'SMT' fluorescence change (Fig. 1). This compares well with green algae (see Papageorgiou and Govindjee, 1968), except that here the ' $P$ ' level is lower than the ' $T$ ' level, perhaps because of a slightly greater ratio of PS I to PS II activity than in other algal cells. The most striking difference as a result of the $\mathrm{LD}$ to $\mathrm{LL}$ transfer is a change in the time course and nature of the fluorescence induction curves. Cells of $G$. polyedra in LL displayed a faster fluorescence rise to ' $P$ ', and a different pattern of fluorescence decline to the level ' $T$ ', without the usual slow 'SMT' fluorescence change, which is replaced by an indistinct SMT transient, ' $M$ ' appearing at $10 \mathrm{~s}$ in contrast to $45 \mathrm{~s}$ in LD cells. Since the gross pigment content per cell is not significantly different between $L D$ and $L L$ cells, the absorption per cell is almost constant for the same number of incident quanta. Thus, compared to $\mathrm{LD}$ cells, the shorter time needed to reach ' $P$ ' in LL cells cannot be related to the intensity-dependent nature of ' $P$ ' (Munday, 1968), but is due either to a more efficient use of absorbed quanta in the initial photochemical transformations of PS II or to a 


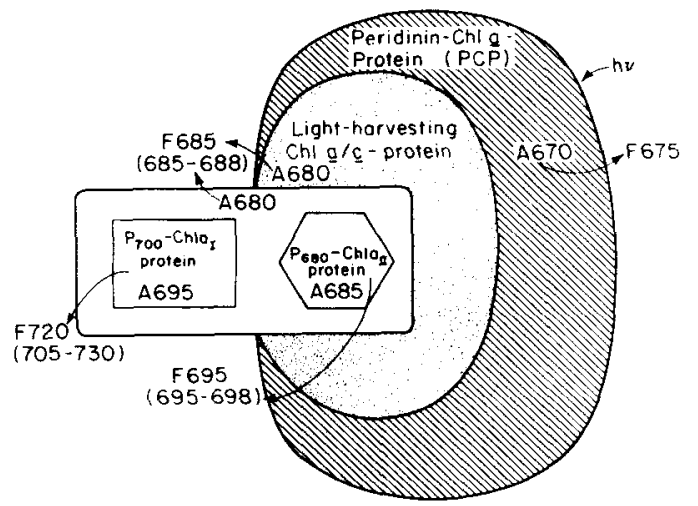

Figure 5. A working model for the possible assignment of absorption (A) and emission (F) maxima, in $\mathrm{nm}$, to the various Chl $a$ complexes in $G$. polyedra (cf. Prézelin and Alberte, 1978)

slower interaction with PS I (also, see Results). Support for this possibility comes from arguments that the efficiencies of energy transfer from Chl $a$ in PCP to the other antenna $\mathrm{Chl} a$ and from PCP and $\mathrm{Chl}$ $a_{11}$ to the reaction center II is probably higher in LL cells (Figs. 2, 4).

The different characteristics of fluorescence decline from ' $P$ ' to ' $T$ ' in LL cells may be related to the differences in the distribution, between PS I and PS II, of electronic excitation of Chl $a$ by the light-harvesting pigments or of changes in $\mathrm{H}^{+}$(inside) which affect the state of the membrane (Papageorgiou, 1975). It has been suggested that the ' $P$ ' to ' $S$ ' decay is affected by the rate of photoconversion of the photosynthetic apparatus from state I (low 'spillover' state; more $\mathrm{Mg}^{2+}$ or less $\mathrm{H}^{+}$in the thylakoid) to state II (high 'spillover' state; less $\mathrm{Mg}^{2+}$ or more $\mathrm{H}^{+}$in the thylakoid); in state II more energy spills over from the strongly fluorescent PS II to the weakly fluorescent PS I (see Govindjee and Papageorgiou, 1971; Mohanty and Govindjee, 1974). If the initial distribution of absorbed light between the photosystems had been altered by the photo-adaptation to LL conditions, then it would be expected that the fluorescence kinetics would also be affected. There were several suggestions in this paper that excitation energy flow had indeed changed.

The usual 'SMT' transient was not seen in LL cells although measurements were made over a wide range of light intensities. These slow fluorescence changes were obscured since the entire transient occurred faster and the 'M' was at $10 \mathrm{~s}$. Slow fluorescence changes are complicated phenomena, being responses to State I-State II photoconversion or to membrane alterations caused by changes in phosphorylating conditions (see above discussion). In any case it seems clear that 'SMT' transients are due to differences in the organization of the pigment complexes in the thylakoid membrane. It appears that a higher PS II/PS I activity in LL cells can explain most of the differences between LL and LD cells.
All the fluorescence transient differences described here were constant features of LD and LL cells, not dependent either on the preparation procedure or the time of the day.

\section{(2) Fluorescence emission spectra: four Chl a complexes}

The fluorescence emission curves of $G$. polyedra at $77 \mathrm{~K}$ show an obvious lack of dominant bands at 695-698 nm (ChI $\left.a_{\mathrm{II}}\right)$ and $720-740 \mathrm{~nm}$ (F730) (Figs. 2 and 3). This is in sharp contrast to 3- or 4-peaked emission curves described for most other algae and chloroplasts from higher plants (Govindjee, 1966; Cederstrand and Govindjee, 1966; Govindjee and Yang, 1966; Krey and Govindjee, 1966; Gasanov and Govindjee, 1974; Rijgersberg et al., 1979). However, a similar situation is observed in the diatoms (Goedheer, 1972).

In spite of the simplicity of the emission spectra presented for $G$. polyedra, a careful examination of the absorption spectra, emission spectra (Figs 2 and 3), difference emission spectrum between LL and LD cells (Fig. 2, inset), ratio spectrum between DCMUtreated and control cells (Fig. 3 inset), the excitation spectra of Chl a fluorescence (Fig. 4) and the difference excitation spectrum (Fig. 4) together reveal that $G$. polyedra contains at least four $\mathrm{Chl}$ a complexes (in addition to those in the two reaction center $I$ and II which are, perhaps, so weakly fluorescent that they cannot be observed) (Fig. 5). Based on approximate Stoke's shifts of $5-15 \mathrm{~nm}$, we use their possible absorption peaks as subscripts and their possible emission peaks as superscripts, the following Chl a spectral forms must be present in $G$. polyedra: $\mathrm{Chl}$ $a_{670}^{675}$ (antenna Chl $a$ in peridinin $\mathrm{Chl}$ a complex, PCP); Chl $a_{678-681}^{686-687}$ (antenna Chl $a$, possibly in Chl $a-\mathrm{Chl} c$ complexes; $\mathrm{Chl} c$ is non-fluorescent because it transfers energy with $100 \%$ efficiency to this $\mathrm{Chl}$ a); Chl $a_{\mathrm{II} 685}^{690-695}$ (associated with Chl a 685 close to reaction center II); and Chl $a_{1690-705}^{705-720}$ (associated with Chl $a$ 695, close to reaction center I) (see Prézelin and Alberte, 1978, for a model of organization of these complexes). A fifth minor band fluorescing around $730 \mathrm{~nm}$ is inferred from a comparison of the $77 \mathrm{~K}$ emission spectra of LL and LD cells treated with DCMU: this emission in LD - LL difference spectra (not shown) could not be from $\mathrm{Chl} a_{1690-705}^{705-720}$ because the difference emission at $730 \mathrm{~nm}$ is positive but that at $710 \mathrm{~nm}$ is negative; it could, however, be from another minor long-wavelength-emitting complex.

\section{(3) Energy distribution and transfer in PS I and PS II}

The inability to observe PS I activity through $P_{700}$ changes (Prézelin, et al., 1976) or the intense F730 band in intact cells of $G$. polyedra (Figs. 2 and 3) and a Glenodinium sp. suggest something new about this group of algae. It could be that the spectral differences between PS I and II are minimal in these algae, and the balanced excitation of the two 
pigment systems does not allow net oxidation or reduction of $\mathrm{P} 700$ in vivo. That $\mathrm{PCP}$ is $100 \%$ efficient in transferring absorbed light energy to other Chl $a$ complexes and in promoting whole cell oxygen evolution, has been previously demonstrated (Prézelin and Haxo, 1976; Prézelin et al., 1976; Song et al., 1976). Interestingly, the transfer of cells from $L D$ to $\mathrm{LL}$ seems to alter slightly the energy distribution pattern (see Results) in the photosynthetic apparatus.

It is clear that the changes brought on by the LD to LL transfer reflect adaptive processes, independent of regulation by a biological clock, in which $G$. polyedra adjust chlorophyll organization and excitation energy distributions to deal, perhaps, with physiological changes imposed by lowering incident light levels and daylength prolonged to $24 \mathrm{~h}$. In another paper (Sweeney et al., 1979), we have presented our data on the circadian rhythm in fluorescence intensities at various points on the fluorescence transient curves.

Acknowledgements - We are particularly thankful to Rita Khanna for maintaining our cultures at Urbana, Illinois. We also thank Malcolm Sargent, Thomas Lonergan and Rajni Govindjee for their help during the present studies, and Brigitte Walz for her careful reading of this manuscript. Financial support from National Science Foundation to Govindjee (PCM 76-11657), to Beatrice $M$. Sweeney (PCM 77-07709) and to Barbara B. Prézelin (OCE 77 13919) is acknowledged.

\section{REFERENCES}

Boardman, N. K., J. M. Anderson and D. J. Goodchild (1978) Curr. Topics Bioenerget. 8, 35-109. Cederstrad, C. N. and Govindjee (1966) Biochim. Biophys. Acta 120, 177-178.

Cho, F. (1969) Ph.D. Thesis in Biophysics, University of Illinois at Urbana-Champaign.

Duysens, L. N. M. (1952) Ph.D. Thesis, The State University of Utrecht, The Netherlands.

Duysens, L. N. M. and H. Sweers (1963) In Studies in Microalgae and Photosynthetic Bacteria (Edited by Japanese Society of Plant Physiologist), pp. 352-372, Tokyo, Japan.

Emerson, R. and C. M. Lewis (1942) J. Gen. Physiol. 25, 579-595.

Gasanov, R. and Govindjee (1974) Z. Pflanzenphysiol. 72, 193-202.

Goedheer, J. H. C. (1972) Ann. Rev. Pl. Physiol. 23, 87-112.

Govindjee (1966) In Currents in Photosynthesis (Edited by J. B. Thomas and J. H. C. Goedheer), pp. 93-103. Ad Donker, Rotterdam.

Govindjee and J.-M. Briantais (1972) FEBS Lett. 19, 278-280.

Govindjee and G. Papageorgiou (1971) Photophysiology 6, 1-46.

Govindjee and D. Wong (1978) Proc. 3rd Internat. Seminar held in 1976 on Excitation Energy Transfer in Condensed Matter (Edited by J. Fiala), pp. 19-28. Univerzita Karlova, Praha, Czechoslovakia.

Govindjee and L. Yang (1966) J. Gen. Physiol. 49, 763-780.

Govindjee, G. Papageorgiou and E. Rabinowitch (1973) In Practical Fluorescence Theory, Methods and Techniques (Edited by G. G. Guilbault), pp. 543-575. Marcel Dekker, New York.

Guillard, R. R. L. and J. H. Ryther (1962) Can. J. Microbiol. 8, 229-239.

Hastings, J. W., L. Astrachan and B. M. Sweeney (1961) J. Cell. Physiol. 45, 69-76.

Jeffrey, S. W., M. Seilicki and F. T. Haxo (1975) J. Phycol. 11, 374-384.

Koka, P. and P. S. Song (1977) Biochim. Biophys. Acta 495, 220-231.

Krey, A. and Govindjee (1966) Biochim. Biophys. Acta 120, 1-18.

Lavorel, J. and A. L. Etienne (1977) In Primary Processes of Photosynthesis (Edited by J. Barber), pp. 203-268. Elsevier, Amsterdam.

Mar, T. and Govindjee (1972) In Photosynthesis, Two Centuries After Its Discovery by Josephy Priestly (Edited by G. Forti, M. Avron and A. Melandri), pp. 271-281. Dr. W. Junk, The Hague.

Mohanty, P. K. and Govindjee (1974) Pl. Biochem. J. 1, 78-106.

Munday, J. C. Jr. (1968) Ph.D. Thesis in Biophysics, University of Illinois at Urbana-Champaign.

Munday, J. C., Jr. and Govindjee (1969) Biophys. J. 9, 1-21.

Papageorgiou, G. (1975) In Bioenergetics of Photosynthesis (Edited by Govindjee), pp. 319-371. Academic Press, New York.

Papageorgiou, G. and Govindjee (1968) Biophys. J. 8, 1299-1328.

Prézelin, B. B. (1978) Abstr. Limnol. Oceanog., p. 10.

Prézelin, B. B. and R. S. Alberte (1978) Proc. Natl. Acad. Sci. U.S.A. 75. 1801-1804.

Prézelin, B. B. and F. T. Haxo (1976) Planta 128, 133-141.

Prézelin, B. B. and B. M. Sweeney (1977) Pl. Physiol. 60, 388-392.

Prézelin, B. B., A. C. Ley and F. T. Haxo (1976) Planta 130, 251-256.

Prézelin, B. B., B. W. Meeson and B. M. Sweeney (1977) Pl. Physiol. 60, 384-387.

Rijgersberg, C. P., J. Amesz, A. P. G. M. Thielen and J. A. Swager (1979) Biochim. Biophys. Acta, $545,473-482$.

Shimony, C. J. Spencer and Govindjee (1967) Photosynthetica 1, 113-125.

Song, P.-S., K. Prasad, B. B. Prézelin and F. T. Haxo (1976) Biochemistry 15, 4422-4427.

Sweeney, B. M. (1977) In The Science of Photobiology (Edited by K. C. Smith), pp. 209-227, Planum/ Rosetta.

Sweeney, B. M. and B. B. Prézelin (1978) Photochem. Photobiol. 27, 841-847.

Sweeney, B. M., B. B. Prézelin, D. Wong and Govindjee (1979) Photochem. Photobiol. 30, 251-256.

Thornber, J. P., R. S. Alberte, F. A. Hunter, J. A. Shiozawa and K. S. Kan (1976) Brookhaven Symp. Biol. 28, 132-148.

Van Rensen, J. J. S., D. Wong and Govindjee (1978) $\quad$ Z. Naturforsch. 33c, 413-420. 